\title{
Sustainable sludge management - its use for remediation of degraded lands
}

https://doi.org/10.21698/rjeec.2020.224

Proceedings Paper

\section{VALERIA NICORESCU ${ }^{1 *}$, LADISLAU ANDRES $^{1}$, SORINA CLAUDIA NEGREA $^{1}$, DORIAN GABRIEL NEIDONI $^{1}$, CAROL BLAZIU LEHR ${ }^{1}$, CORINA ORHA ${ }^{2}$}

\author{
${ }^{1}$ National Research and Development Institute for Industrial Ecology-ECOIND, Timisoara Branch, 115 Bujorilor, \\ 300431, Timisoara, Romania \\ ${ }^{2}$ National Institute for Research and Development in Electrochemistry and Condensed Matter, Condensed Matter \\ Department, 1 P. Andronescu, 300254, Timisoara, Romania \\ *Corresponding author (e-mail): valeria.nicorescu@incdecoind.ro
}

\begin{abstract}
The sludge resulted from the urban wastewater treatment plants, can be used, from a circular economy, as a fertilizer for agricultural and degraded lands, for horticulture and forestry.

This paper aims to propose an alternative for the use of this type of sludge in a sustainable way, with a low impact on the environment. The study consisted of experiments done to recover the stabilized sludge from the urban wastewater treatment plants in the process of degraded land rehabilitation, using the energetic willow, Salix sp.

The experimental results showed that the use of stabilized sludge as fertilizer for naturally and anthropogenic degraded lands determined the improvement of nutritional characteristics of the lands cultivated with Salix sp., and allowed the growth, development, and maintenance of this plant. Taking into consideration the characteristics of the cultures and the quantities of metals accumulated by Salix sp., it can be concluded that these plants were adapted to the environmental conditions and the substrate toxically composition. The results obtained on two degraded lands indicate that Salix sp. can be used for its introduction in the economic circuit, both for salty soils and ash dumps.
\end{abstract}

Keywords: sludge, degraded land, circular economy

\section{INTRODUCTION}

The European Environmental Legislation raises extremely complex issues on how to approach the sludge disposal. The Urban Wastewater Directive (91/271/EEC) requests the treatment of effluents for inhabited areas of a certain size, this approach leading to an increase of the sludge volume generated from treatment plants [1].

At the EU level, there are different options for sludge disposal from sewage treatment plants. The most common methods consist of sludge deposition in non-hazardous waste landfills (50$70 \%$ ), use as organic fertilizer, incineration/coincineration, co-processing (in cement factories), etc.

Processing of sludge from wastewater treatment plants is following EU policy on the application of the circular economy principles and the National Sludge Management Strategy [2-4]. The sludge recovery options target two directions, energy recovery, and agricultural use. Due to the content of organic matter, macro- and micro-nutrients, the sludge is suitable to be used as fertilizer.
The Directive no. 86/278 / EEC [5] transposed by Order no. $344 / 708$ on the approval of technical norms for the environmental protection and especially of soils, when using the sludge from wastewater treatment plants in agriculture, provides limits for the sludge used in agriculture as well as for the soils on which it is stored [6]. To establish the doses of sludge applied as organic fertilizer, it is necessary to know the land quality by performing periodic analytical control.

Degraded soils are poor in nutrients and organic matters and may contain toxic elements, and also may present high acidity or alkalinity [7, 8]. For the restoration of these lands, the soils can be covered with fertile soil, and/or mineral fertilizers can be used. These methods are too expensive. A cheaper and successful alternative to these processes is the use the sludge from urban wastewater treatment plants as fertilizer [9-11].

Starting from these aspects, in this paper are presented the results based on the experimental studies related to the use the sludge, resulting 
from urban wastewater treatment plants, as a fertilizing agent for naturally salty lands and anthropogenic degraded areas (ash dumps) [12, 13]. For the restoration/rehabilitation of the degraded lands, it was decided to apply the phytoremediation process using the culture of

\section{EXPERIMENTAL PART}

Experimental studies on the restoration/ rehabilitation of degraded soils were performed in-situ on two types of land: one natural degraded land (salty land) and on the surface of an ash dump.

To increase the rate of organic matter and nutrients (NPK mainly), the experimental lots were fertilized with stabilized sludge from the urban wastewater plant and manure from a pig farm. The characteristics of the stabilized sludge and the manure are presented in tables 1 and 2. The experimental lots were fertilized with $40 \mathrm{t} / \mathrm{ha}$ of stabilized sludge and $80 \mathrm{~m}^{3} / \mathrm{ha}$ the energetic willow, Salix sp. The advantage of this method is that Salix sp. can remove the soluble salts and the metals $(\mathrm{Zn}, \mathrm{Ni}, \mathrm{Cu}, \mathrm{Fe}$, $\mathrm{Mn}, \mathrm{Pb}$ ) from soil depth due to its root system and, in the same time, can be used as a renewable energy source $[14,15]$.

of manure. The incorporation of the fertilizers in the superior layer $(0-30 \mathrm{~cm})$ was realized on the same day.

The meaning of experimental lots: LD experimental lot on salty land and fertilized with manure; LN - experimental lot on salty land and fertilized with stabilized sludge; HD experimental lot placed on ash dump fertilized with manure and $\mathrm{HN}$ - experimental lot placed on ash dump fertilized with stabilized sludge. Each experimental lot was divided into three sublots.

Table 1. Characteristics of the stabilized sludge used for fertilization

\begin{tabular}{|c|c|c|c|}
\hline Parameter & Measurement unit & $\begin{array}{l}\text { Average determined } \\
\text { value }\end{array}$ & $\begin{array}{c}\text { Limit values for metal } \\
\text { concentration in sludge [6] }\end{array}$ \\
\hline $\mathrm{pH}$ & - & 7.7 & - \\
\hline Humidity & $\%$ & 71.4 & - \\
\hline Volatile matter & $\%$ & 64.2 & - \\
\hline Total N & $\%$ & 3.15 & - \\
\hline Total P & $\%$ & 0.904 & - \\
\hline $\mathrm{Cd}$ & mg/kg d.m. & 2.64 & 10 \\
\hline $\mathrm{Cr}$ & $\mathrm{mg} / \mathrm{kg}$ d.m. & 35.4 & 500 \\
\hline $\mathrm{Cu}$ & mg/kg d.m. & 47.7 & 500 \\
\hline $\mathrm{Fe}$ & $\mathrm{mg} / \mathrm{kg}$ d.m. & 418 & - \\
\hline Mn & mg/kg d.m. & 1107 & - \\
\hline $\mathrm{Ni}$ & $\mathrm{mg} / \mathrm{kg}$ d.m. & 38.8 & 100 \\
\hline $\mathrm{Pb}$ & $\mathrm{mg} / \mathrm{kg}$ d.m. & 41.4 & 300 \\
\hline $\mathrm{Zn}$ & $\mathrm{mg} / \mathrm{kg}$ d.m. & 298 & 2000 \\
\hline $\mathrm{K}$ & mg/kg d.m. & 2784 & - \\
\hline BTEX & mg/kg d.m. & $<0.01$ & - \\
\hline
\end{tabular}

Note: d.m. $=$ dry matter

Table 2. The manure characteristics from a pig farm

\begin{tabular}{cccccc}
\hline Parameter & $\begin{array}{c}\text { Measurement } \\
\text { unit }\end{array}$ & $\begin{array}{c}\text { Average } \\
\text { determined } \\
\text { value }\end{array}$ & Parameter & Measurement unit & $\begin{array}{c}\text { Average } \\
\text { determined } \\
\text { values }\end{array}$ \\
\hline $\mathrm{pH}$ & - & 7.6 & $\mathrm{Cd}$ & $\mathrm{mg} / \mathrm{kg} \mathrm{d} . \mathrm{m}$ & $<0.5$ \\
Humidity & $\%$ & 99.2 & $\mathrm{Cr}$ & $\mathrm{mg} / \mathrm{kg} \mathrm{d} . \mathrm{m}$ & 2.1 \\
Volatile matter & $\%$ & 51.6 & $\mathrm{Cu}$ & $\mathrm{mg} / \mathrm{kg} \mathrm{d} . \mathrm{m}$ & 164 \\
Total N & $\%$ & 0.14 & $\mathrm{Ni}$ & $\mathrm{mg} / \mathrm{kg} \mathrm{d.m}$ & 10.2 \\
$\mathrm{P}_{2} \mathrm{O}_{5}$ & $\%$ & 0.12 & $\mathrm{~Pb}$ & $\mathrm{mg} / \mathrm{kg} \mathrm{d} . \mathrm{m}$ & $<0.5$ \\
$\mathrm{~K}_{2} \mathrm{O}$ & $\%$ & 0.18 & $\mathrm{Zn}$ & $\mathrm{mg} / \mathrm{kg} \mathrm{d.m}$ & 513 \\
\hline
\end{tabular}


The stabilized sludge used for the fertilization of experimental lots presents an average content of organic matter, nutrients, and the metal concentrations within the limits provided by Order 344/708/ 2004.

The manure used was liquid, with an organic matter content of $51.6 \%$ and the nutrients content smaller than in the stabilized sludge. The metal concentrations are within the limits provided by Order 344/708 [6].

Metals such as $\mathrm{Zn}$ and $\mathrm{Cu}$ found in the manure come mainly from the additives and

\section{Methods of analysis}

The soil samples were collected from five points on each experimental sublot, from a depth between $5-20 \mathrm{~cm}$.

The soil samples were processed by mineralization with aqua regia and analyzed by atomic absorption spectrophotometry according to SR ISO 11466:1999 [17] and SR 1331596/C91:2008 for Fe [18, 19] methods, using an

\section{Method of calculation}

The bioaccumulation (transfer) factor, BF, represents the bioavailability of metals in the upper soil layers and their transfer to the plants $\mathrm{BF}=\mathrm{C}_{\mathrm{t}} / \mathrm{C}_{\mathrm{s}}$

where $C_{t}$ - concentration of metal in the Salix

\section{Statistical analysis}

The values of the metal concentrations determined in the soil and the Salix sp. stems

\section{RESULTS AND DISCUSSION}

During the experiments, was determined the concentration of metals (Fe, Mn, $\mathrm{Zn}, \mathrm{Ni}, \mathrm{Cu}$, supplements used in pig food. The capacity of $\mathrm{Cu}$ absorption in soil determines the toxic action on the plants. As for $\mathrm{Zn}$, it presents reduced toxicity for animals and can be accumulated easily and in a large proportion in the green parts of the plants [16].

Due to the content of nutrients (nitrogen, phosphorus, potassium, microelements) and the organic matter concentration, the stabilized sludge and the pig manure are considered very useful as soil fertilizers.

Avanta atomic absorption spectrophotometer.

To determine metals in Salix sp. the stem was chosen because this part of the plant is a better pollution indicator than leaves, due to the longer period of exposure to heavy metals. At the same time, the stems of Salix sp. can be used as a source of renewable energy.

$[20,21]$. With the use of the bioaccumulation factor, one can evaluate the phytoremediation potential of certain plants.

sp. stem, and $C_{s}-$ concentration of metal in soil.

represent the average of five samples taken from each sublot.

$\mathrm{Pb}$ ) accumulated by Salix sp., during two phenological stages of vegetation.

Determination of metals in Salix sp. cultivated on salty soil

Figures 1 and 2 show the quantities of metals determined on Salix $s p$. in the $2^{\text {nd }}$ year of vegetation (after 12, 15, and 18 months from cultivation) on a salty land and fertilized with manure and stabilized sludge.

The amounts of metals accumulated in Salix sp. plants increased with the increasing time of vegetation. During the $2^{\text {nd }}$ year of vegetation, it was found that Salix sp. cultivated on salty lots fertilized with manure had a high accumulation capacity for $\mathrm{Zn}, \mathrm{Mn}$, and Fe. The amount of $\mathrm{Zn}$ accumulated after 18 months from cultivation shows an increase of about $41-45 \%$ in comparison with the stems harvested after 12 months. For $\mathrm{Mn}$ and $\mathrm{Fe}$ the increase was of 31$35 \%$ and $33-37 \%$, respectively.

The quantities of $\mathrm{Cu}, \mathrm{Ni}$, and $\mathrm{Pb}$ bioaccumulated in Salix sp. were under 100 $\mathrm{mg} / \mathrm{kg}$ d.m., the smallest amount being about 5 $\mathrm{mg} / \mathrm{kg}$ d.m for $\mathrm{Pb}$. 


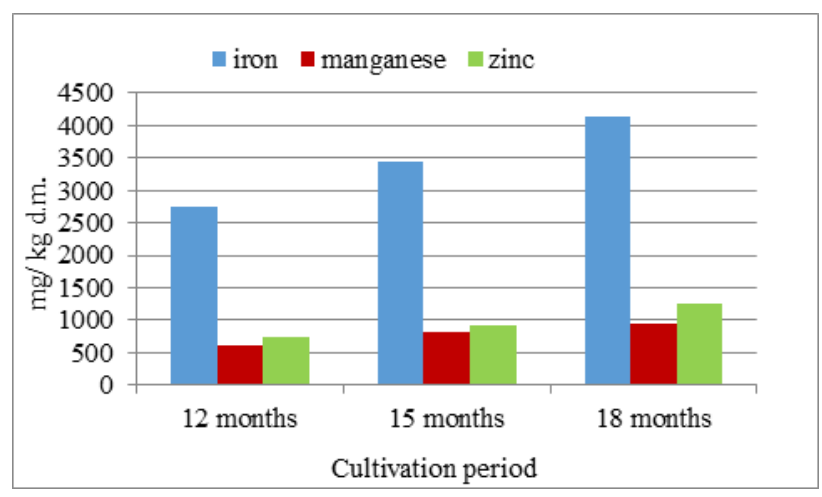

a)

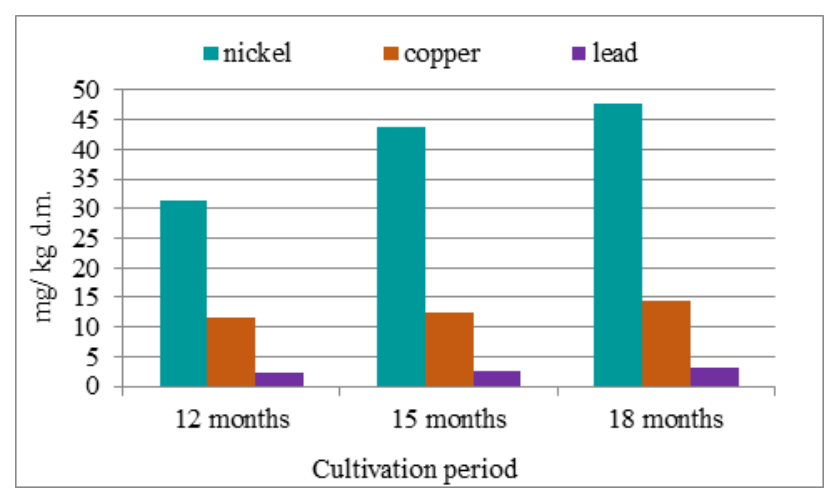

b)

Fig. 1. Quantities of metals accumulated by Salix sp. cultivated on salty land fertilized with manure a) for $\mathrm{Fe}, \mathrm{Mn}, \mathrm{Zn}$, b) for $\mathrm{Ni}, \mathrm{Cu}, \mathrm{Pb}$

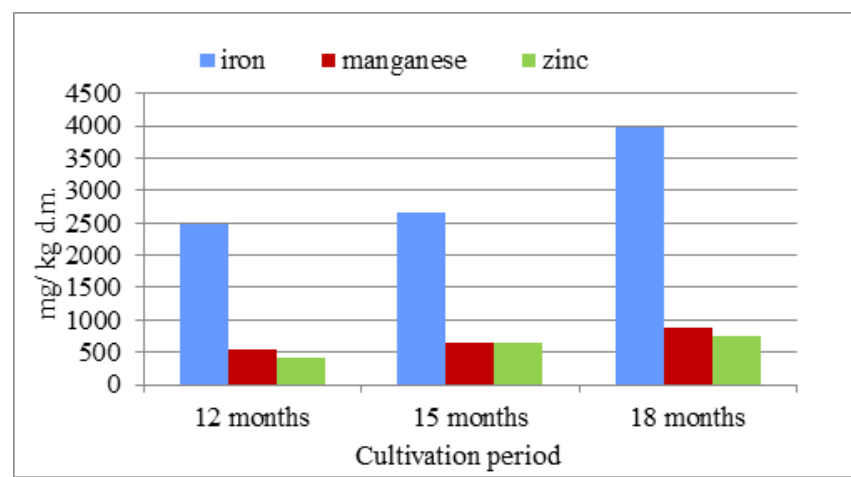

a)

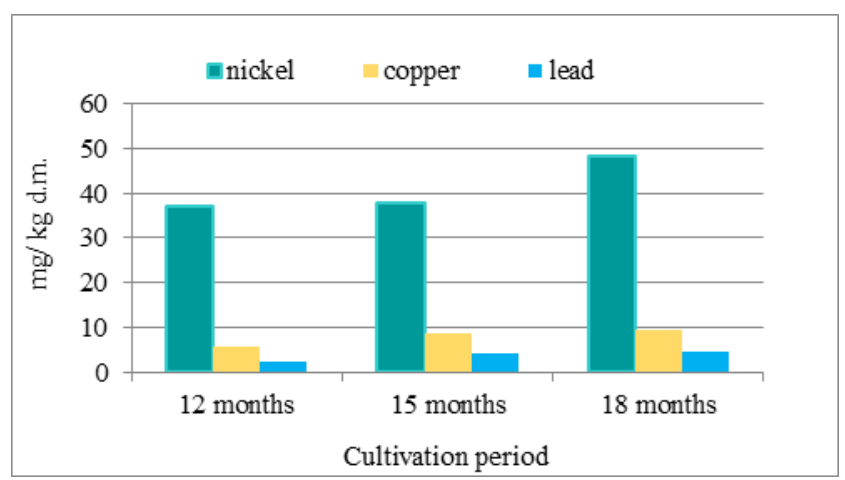

b)

Fig. 2. Quantities of metals accumulated by Salix sp. cultivated on salty land and fertilized with stabilized sludge a) $\mathrm{Fe}, \mathrm{Mn}, \mathrm{Zn}$; b) $\mathrm{Ni}, \mathrm{Cu}, \mathrm{Pb}$

The Salix sp. planted on the experimental lots fertilized with pig manure accumulated higher quantities of metals in comparison with those cultivated on the experimental lots fertilized with stabilized sludge.

The quantities of metals accumulated in the stems of Salix sp. harvested from the experimental lots are in correlation with the data from other studies [21].
The capacity of Salix sp. to accumulate metals varies with the type of willow, the development phase of the plant, and the type of soil. According to previous studies, the concentrations of metals in Salix present a wide range of variations: $145-6900 \mathrm{mg} / \mathrm{kg}$ d.m for $\mathrm{Fe}$, $28-980 \mathrm{mg} / \mathrm{kg}$ d.m. for $\mathrm{Mn}, 41-2087 \mathrm{mg} / \mathrm{kg}$ d.m. for $\mathrm{Zn}, 5.6-24 \mathrm{mg} / \mathrm{kg}$ d.m. for $\mathrm{Cu}$ and $0.4-$ $29 \mathrm{mg} / \mathrm{kg}$ d.m. for $\mathrm{Pb}$ [22- 25].

\section{Determination of metals in Salix sp. cultivated on ash dump}

Figures $3 \mathrm{a}$ and $3 \mathrm{~b}$ show the metal concentrations in Salix sp. cultivated on the ash dump in the I and II phenological stages of vegetation.

The quantities of $\mathrm{Fe}, \mathrm{Zn}$, and $\mathrm{Cu}$ in the stems of Salix sp. were higher for the ash lots fertilized with manure. The samples of Salix sp. collected from the lots fertilized with stabilized sludge presented higher quantities of $\mathrm{Ni}, \mathrm{Mn}$, and $\mathrm{Pb}$ comparing with those collected from the lots fertilized with manure. An explanation for these differences may be the fact that the upper layers of soil have various concentrations of metals and the quantities accumulated by Salix sp. depend on the degree of bioavailability of the metals and nutrients in the soil and on the climatic conditions [21].

The biggest accumulations are of $\mathrm{Fe}, \mathrm{Zn}$, and $\mathrm{Mn}$. The quantities of $\mathrm{Fe}$ accumulated in the stem of Salix sp. after the II $^{\text {nd }}$ phenological stage, are of $3667-3782 \mathrm{mg} / \mathrm{kg}$ d.m., which are smaller than the concentrations reported by Wojtun et al. in 2019 (value of $6900 \mathrm{mg} / \mathrm{kg}$ d.m.) [21].

$\mathrm{Ni}, \mathrm{Cu}$, and $\mathrm{Pb}$ present much lower concentration, situated under $45.8 \mathrm{mg} / \mathrm{kg}$ d.m. 
(Fig. 3b), results being similar to the concentrations reported by the same study [21].

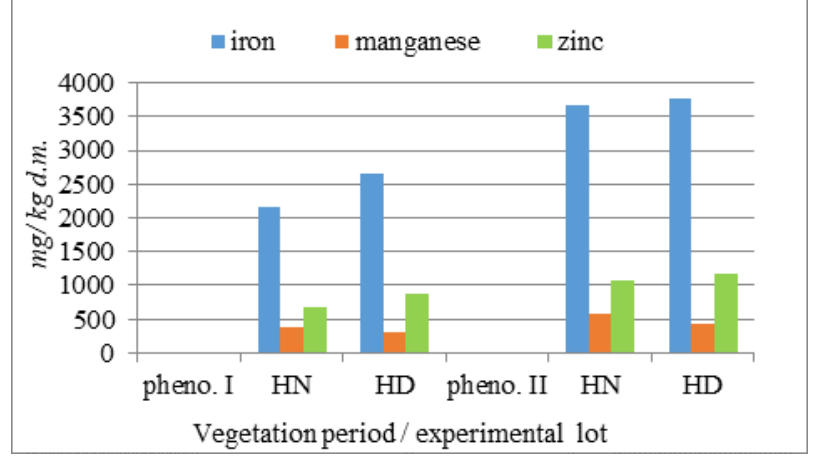

a)

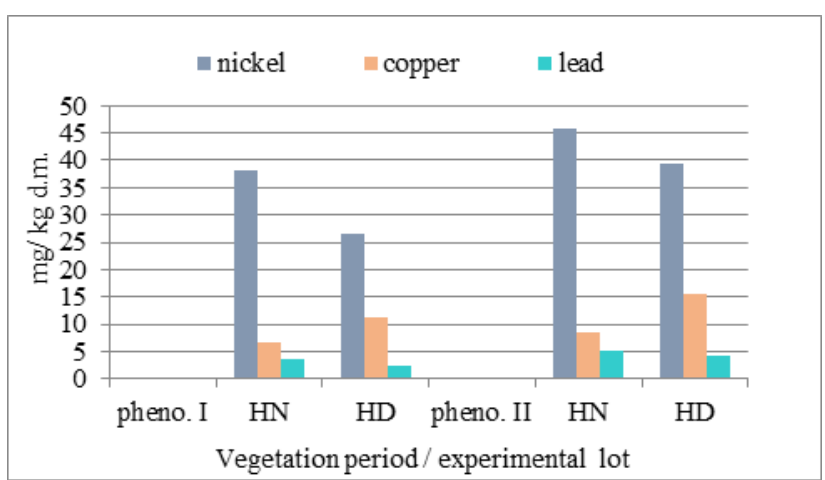

b)

Fig. 3. Quantity of metals in Salix sp. cultivated on ash dump fertilized with stabilized sludge and manure a) $\mathrm{Fe}, \mathrm{Mn}, \mathrm{Zn}$; b) $\mathrm{Ni}, \mathrm{Cu}, \mathrm{Pb}$

Variation of the metal content in Salix sp.

Figures $4 \mathrm{a}$ and $4 \mathrm{~b}$ present a comparison between the quantities of metals accumulated in the Salix sp. planted on the salty land and in the

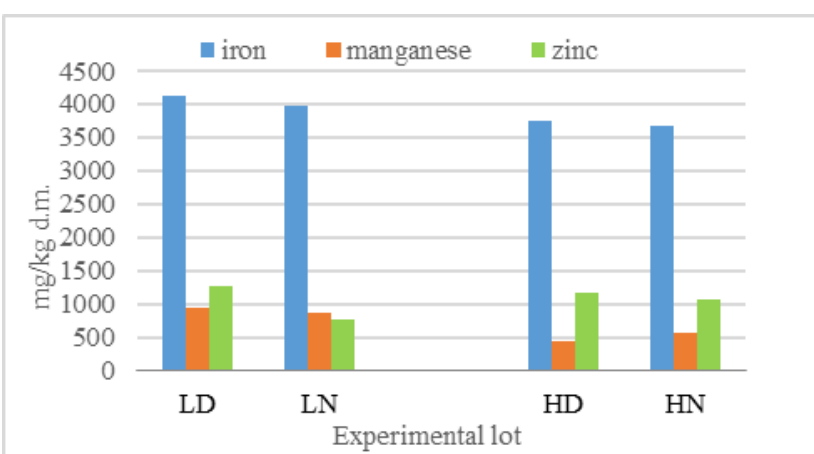

a) ash dump, in the II $^{\text {nd }}$ phenological stage of vegetation.

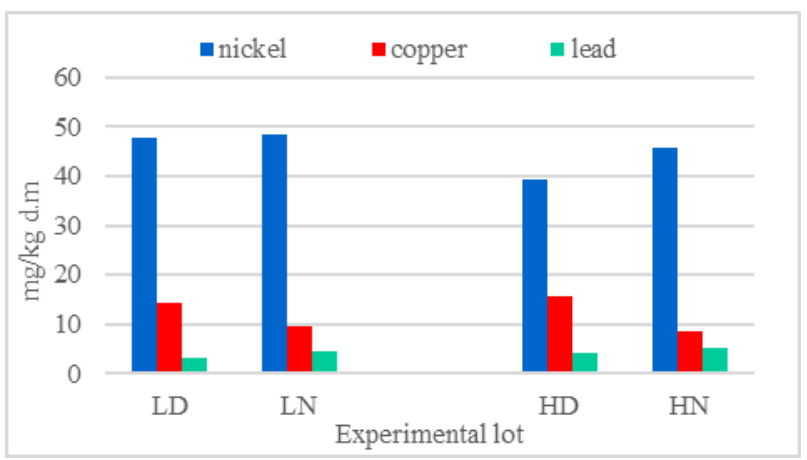

b)

Fig. 4. Quantities of metals in Salix sp. cultivated on salty land and ash dump a) $\mathrm{Fe}, \mathrm{Mn}, \mathrm{Zn}$; b) $\mathrm{Ni}, \mathrm{Cu}, \mathrm{Pb}$

The concentrations of metals accumulated in the stem of Salix sp. was higher in the case of the experimental lots placed on salty land and fertilized with manure in comparison with that one from the ash dump fertilized with stabilized sludge.

The experimental studies confirmed that Salix sp. presents a high capacity of absorption for $\mathrm{Zn}, \mathrm{Mn}$, and $\mathrm{Ni}$.

The quantity of $\mathrm{Zn}$ in the stem of Salix sp. cultivated on the 4 types of experimental lots varied from 762 to $1264 \mathrm{mg} / \mathrm{kg} \mathrm{d} . \mathrm{m}$, the biggest quantity of $\mathrm{Zn}$ being registered on the salty lot

The degree of bioavailability of metals in soil

The increase of metal quantities in Salix sp. is mainly associated with the degree of bioavailability of metals in soil. Figures 5 and 6 fertilized with manure. The accumulated quantity is situated in the interval reported by the previous studies, between $41-2087 \mathrm{mg} / \mathrm{kg}$ d.m [21]. The biggest quantity accumulated in the stem of Salix sp. was that of Mn, of 937 $\mathrm{mg} / \mathrm{kg}$ d.m., also for the salty lot fertilized with manure. The biggest quantity of accumulated $\mathrm{Ni}$ was registered on the salty lots fertilized with manure and stabilized sludge (47.6 and 48.3 $\mathrm{mg} / \mathrm{kg}$ d.m.). The domains of accumulation for $\mathrm{Mn}$ and $\mathrm{Ni}$ are $28-980 \mathrm{mg} / \mathrm{kg} \mathrm{d.m}$. for $\mathrm{Mn}$ and $2.1-45 \mathrm{mg} / \mathrm{kg}$ d.m. for $\mathrm{Ni}$, as reported in previous studies [21].

present the bioaccumulation factors $(\mathrm{BF})$ for $\mathrm{Fe}$, $\mathrm{Mn}, \mathrm{Zn}, \mathrm{Ni}, \mathrm{Cu}$, and $\mathrm{Pb}$ in the experimental lots. 


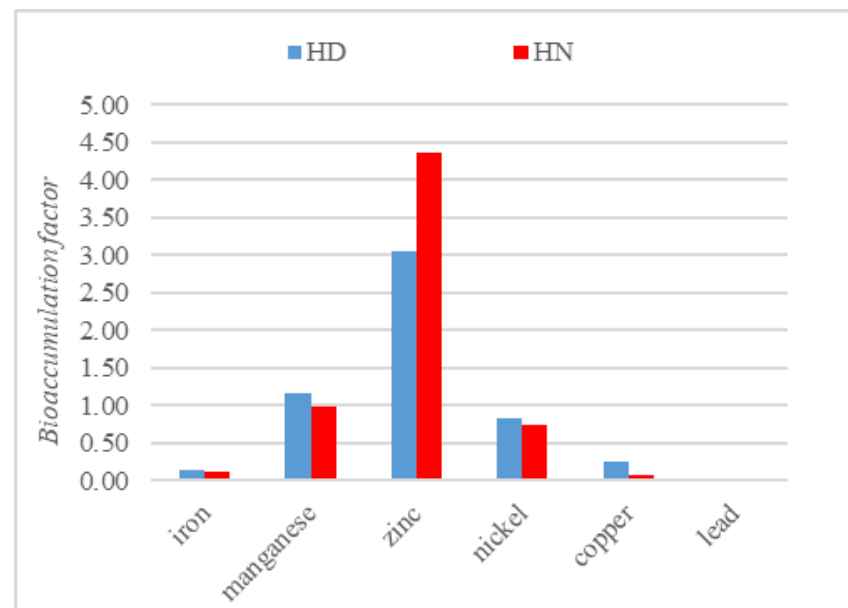

Fig. 5. The bioaccumulation factor of metals in the stems of Salix sp., in the ash dump

$\mathrm{BF}$ values for $\mathrm{Zn}, \mathrm{Mn}, \mathrm{Ni}, \mathrm{Cu}, \mathrm{Fe}$, and $\mathrm{Pb}$ were higher in the case of the salty lands fertilized with pig manure. In the case of the lots situated on the salty land and in the ash dump, the bioaccumulation factors for $\mathrm{Zn}$ and $\mathrm{Mn}$ were higher than 1, with values situated between 3.06-4.42 for $\mathrm{Zn}$ and 1-1.39 for Mn.

$\mathrm{BF}$ for Ni was situated in the range 1.4 to 1.55 in the case of the salty land and between 0.73 0.84 , in the case of the ash dump.

The bioaccumulation factors for $\mathrm{Cu}, \mathrm{Fe}$, and $\mathrm{Pb}$ were lower than 0.5 . The lowest values were registered for $\mathrm{Pb}$, of 0.02 , and, in the case of the lots in the ash dump, of 0.03 . The obtained results are similar with the data from previous studies, which present the following values for BF in Salix polaris: Zn 0.9-6.2; Mn 0.14-1.3; Ni 0.2-1.6; Cu 0.09-0.8; Fe 0.01-0.1; Pb 0.001-0.2 $[21,24,25]$.

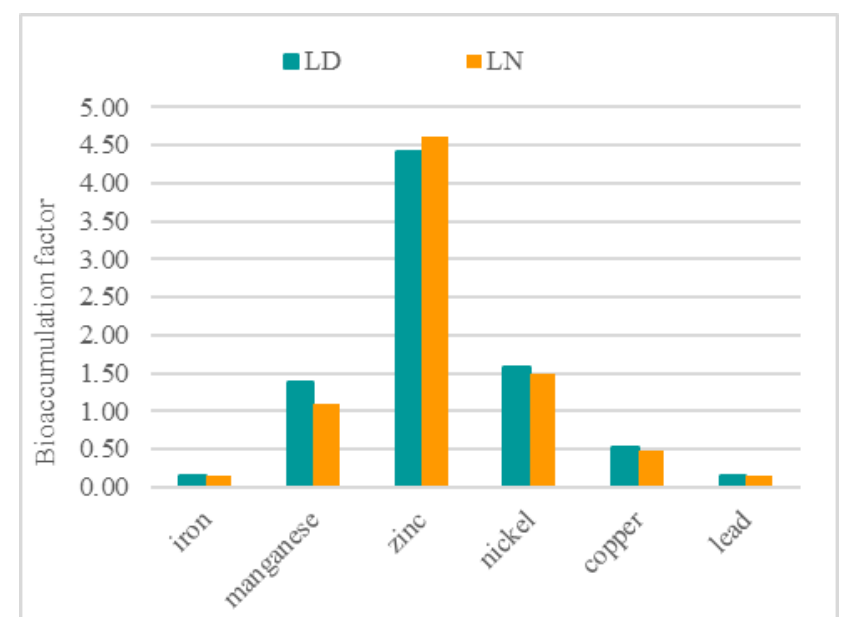

Fig. 6. The bioaccumulation factor of metals in the stems of Salix sp., in the salty land

The BF difference between various fertilization treatments may be an effect of the $\mathrm{pH}$ in the rhizosphere zone. This is in correlation with previous studies that report that the soil $\mathrm{pH}$ greatly influences the concentrations of metals accumulated in the plants [26-28].

The $\mathrm{pH}$ of the lots fertilized with manure was between 5.4 and 5.7, which leads to the increase of metals mobility and availability for plants. According to Qaswar et al. [16], the process of manure degradation in the soil may reduce the pH [16]. Therefore, Salix sp. absorbs the polluting metals instead of macroelements vital for growth and development, so it appears as a nutritional imbalance. This is manifested by slowing down the plant growth rate, drying and premature fall of the leaf, reduction of the photosynthesis process, etc. All these effects lead to a culture of Salix sp. less developed on salty land (Fig. 7).

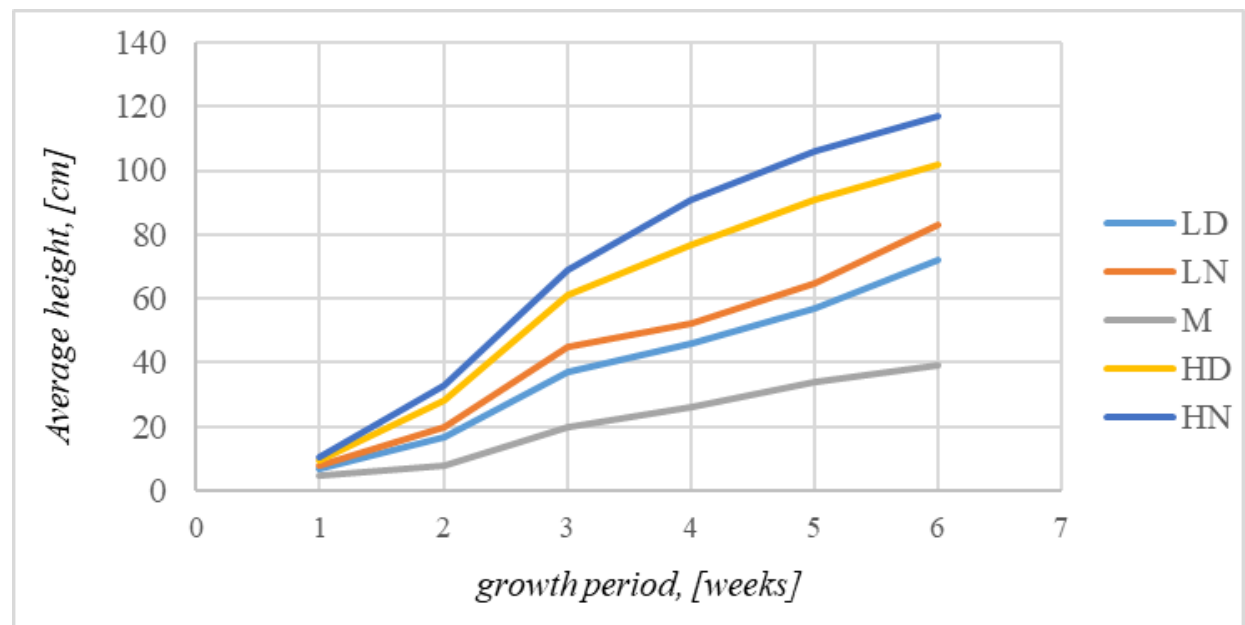

Fig. 7. The average height variation of Salix sp. plants in six months, on the experimental lots and the witness lot 
The $\mathrm{pH}$ of the lots fertilized with stabilized sludge was between 7.3 and 7.7. At these $\mathrm{pH}$ values the possibility of the formation of insoluble hydroxides and carbonates increases. In this case, the metals are less accessible to plants.

The stabilized sludge used as a fertilizer is relatively rich in organic matter, therefore it contributes to the soil's organic matter increase and also the slower and gradual release of heavy metals for plants, due to the absorption

\section{The Salix sp. cultures on the experimental lots}

The monitoring of the Salix sp. cultures took place over six months of vegetation, by the "average height" indicator (Fig. 7). For comparison, there is given the growth variation of Salix sp. on an unfertilized lot in the ash dump (the witness sample - M).

From analyzing the Salix sp. cultures over six months of vegetation was established that the stabilized sludge determines a more vigorous growth and development of the plants in comparison with the plants from the lot fertilized with manure. This development of the plants is correlated also with the higher content of nutrition elements $(\mathrm{N}, \mathrm{P}, \mathrm{K})$ in the lot fertilized with stabilized sludge. After the I $^{\text {nd }}$ phenological stage of vegetation, the Salix sp. culture in the ash dump was better developed than the one raised on the salty land. The plants were vigorous and showed a healthy aspect, presenting no symptom of the sickness of the willow leaves or plants.

Following the evolution of the plants, we can

\section{CONCLUSIONS}

The results of the experimental studies confirm that Salix sp. presents a high accumulation capacity for $\mathrm{Zn}, \mathrm{Mn}$, and $\mathrm{Ni}$. For all experimental lots, the bioaccumulation factors for $\mathrm{Zn}, \mathrm{Mn}$, and Ni presented values higher than 1. The maximum values of the bioaccumulation factor were found for $\mathrm{Zn}$, between 3.06 and 4.42. These results recommend Salix sp. as a bioaccumulator of $\mathrm{Zn}, \mathrm{Mn}$, and $\mathrm{Ni}$, the plant could be used for the bioremediation of polluted soil.

The bioaccumulation factors for $\mathrm{Cu}, \mathrm{Fe}$, and $\mathrm{Pb}$ were lower than 0.5 . The smallest values were for $\mathrm{Pb}, 0.02$ and 0.03 , for the lots situated in the and complexation processes of metals on colloidal surfaces or of other components from the sludge. According to previous studies, this might be the reason for the decrease of the bioaccumulation factor of metals in the case of the ash deposit fertilized with stabilized sludge [29-31]. This is explained by the fact that the culture of Salix $s p$. from the ash dump fertilized with stabilized sludge is more vigorous and has a healthy aspect (Fig. 7).

conclude that the effect of the salinity stress actions on the Salix sp. plants is higher or smaller depending on the soil, humidity, precipitations level, the quantity of sodium over the total quantity of absorbed ions, fertilization level and the ratio between the nutrition substances present in the soil.

The cultures on the witness experimental lots developed harder, the average heights of the plants were $52-76 \%$ shorter than in the case of the cultures raised on the lots from the ash dump fertilized with stabilized sludge. The culture on the witness lots dried out in 9-12 months from its plantation.

Applying stabilized sludge and manure over a long period determines the raise of the nutrient content in the soil and enhances its physical and chemical characteristics $(\mathrm{pH}$, soil porosity, the capacity of retaining water, etc.), determining an optimal growth and development of cultures $[26,27]$.

ash dump.

After the II $^{\text {nd }}$ phenological stage of vegetation, the culture of Salix sp. from the ash dump was much better developed than that one grown on salty soil. The plants were vigorous and presented healthy aspects, no symptoms of the disease of leaves on willow plants were observed.

The salty land causes a higher accumulation of metals in Salix sp. This increase is due to the $\mathrm{pH}$ values of the soil in the rhizosphere area, which favors the increase of mobility and the availability of metals for plants. 


\section{ACKNOWLEDGEMENTS}

The present research was financially supported by the Romanian National "Nucleu" Program

\section{REFERENCES}

[1] Directive 91/271/EEC of 21 May 1991 concerning urban wastewater treatment.

[2] European Commission, COM (2019) - final Bruxelles, 2019.

[3] Romania's National Strategy for Sustainable Development, Horizons 2013-2020-2030.

[4] TARTIU, V.E., STEFANESCU, M., PETRACHE, A.M., GURAU, C.R., The transition to a circular economy. From waste management to a green economy in Romania, SPOS 2018, 3, Bucharest, 2019, p. 32, 41, 76.

[5] Directive 86/278/EEC of 12 June 1986 on the protection of the environment, and in particular of the soil, when sewage sludge is used in agriculture.

[6] Order No. 344/708 from 2004 -Technical rules on the protection of the environment and, in particular, of soils, when sewage sludge is used in agriculture [in Romanian].

[7] DINU, C., UNGUREANU, E.M., VASILE, G.G., KIM, L., SIMION, M., IONESCU, I., ENE, C., Rev. Chimie., 69, no.1, 2018, p. 14, https://doi.org/10.37358/RC.18.11.6722.

[8] DINU, C., VASILE, G.G., BULEANDRA, M., POPA, D.E., GHEORGHE, S., UNGUREANU, E.M., J. Soil. Sediment., 20, no.4, 2020, p.2141, https://doi.org/10.1007/s11368-019-02550.

[9] MASU, S., RUS, V., NICOLAU, M., 2014, RO 128743B1.

[10] MEENA, M.D., YADAV, R.K., NARJARY, B., YADAV, G., JAT, H.S., SHEORAN, P., MEENA, M.K., ANTIL, R.S., MEENA, B.L., SINGH, H.V., MEENA, V., RAI P.K., GHOSH, A., MOHARANA, P.C., Waste Manag., 84, 2019, p. 38, https://doi.org/10.1016/j.wasman.2018.11.020.

[11] GHEORGHE, S., VASILE, G.G., STOICA, C., NITA-LAZAR, M., LUCACIU, I., BANCIU, A, Rev. Chim., 67, no.8, 2016, p. 1469

[12] EGAMBERDIEVA, D., WIRTH, S., BELLINGRATH-KIMURA, S.D., MISHRA, J., ARORA, N.K., Front. Microbiol., 2019, https://doi.org/10.3389/fmicb.2019.02791.

[13]SHRIVASTAVA, P., KUMAR, R., Saudi J. Biol Sci., 22, 2015, p.123,
(PN 162503 08).

https://doi.org/10.1016/j.sjbs.2014.12.001.

[14] NICORESCU, V., MASU, S., ANDRES, L., PASCU, L.F., VLAICU, I., BOZAN, B., HOLLERBACH, W., TRAVA, Rev. Chim., 69, no. $1, \quad 2018 \quad$ p. 45 , https://doi.org/10.37358/RC.18.1.6042.

[15] tthp://www.rebina.ro/salcie-energetica.

[16] QASWAR, M., YIREN, L., JING, H., KAILLOU, L., MUDASIR, M., ZHENZHEN, L., HONGQIAN, H., XIANJIN, L., JIANHUA, J., AHMED, W., DONGCHU, LI., HUIMIN, Z., J. Soils Sediment., 20, 2020, p. 2093, ttps://doi.org/10.1007/s11368-020-02576-5.

[17] ISO 11047:1998 - Soil quality. Determination of cadmium, chromium, cobalt, copper, lead, manganese, nickel and zinc of soil extracts in royal water. Methods by atomic flame absorption spectrometry and electro thermal atomization.

[18] SR 13315:1996/SR 13315:1996/C91:2008 - Water quality. Determination of iron content. Spectrometric method of atomic absorption, www.asro.ro, [in Romanian].

[19] ISO 11466:1995 - Soil quality. Extraction of microelements soluble in aqua regia water.

[20] XIAO, R., WANG, S., LI, R., WANG, J.J., ZHANG, Z., Ecotoxicology and Environmental Safety, 141, 2017, p. 17, https://doi.org/10.1016/j.ecoenv.2017.03.002.

[21] WOJTUŃ, B., POLECHOŃSKA, L., PECH, P., MIELCARSKA, K., SAMECKACYMERMAN, A., SZYMAŃSKI, W., KOLON, M., KOPEĆ, M., STADNIK, K., KEMPERS, A.J., Polar Biol, 42, 2019, p. 1287, https://doi.org/10.1007/s00300-019-02517-0.

[22] VYSLOUZILOVA, M., TLUSTOS, P., SZAKOVA, J., Plant. Soil. Environ., 49, no 12, 2003, p. 542.

[23] VYSLOUZILOVA, M., TLUSTOS, P., SZAKOVA, J., Plant. Soil. Environ., 49, no 5, 2003, p. 191, DOI: 10.17221/4112-PSE.

[24] KIM, H.T., KIM, J.G., Sci. Total Environ., 610-611, 2018, p. 1210.

[25] ZARUBOVA, P., HEJCMAN, M., VONDRACKOVA, S., MRNKA, L., SZAKOVA, J., TLUSTOS, P., Environ. Sci. Pollut. Res., 22, 2015, p. 18801, 
https://doi.org/10.1007/s11356-015-5043-0. [26] ZENG, F., ALI, S., ZHANG, H., OUYANG, Y., QIU, B., WU, F., ZHANG, G., Environ. Pollut, 159, 2011, p. 84, https://doi.org/10.1016/j.envpol.2010.09.019.

[27] YANG, J., PAN, X., ZHAO, C., MOU, S., ACHAL, V., AL-MISNED, F.A., MORTUZA, M.G., GADD, G.M., Geomicrobiol J, 33, 2016, p. 261,

https://doi.org/10.1080/01490451.2015.1068889. [28] FEI, X., XIAO, R., CHRISTAKOS, G., LANGOUSIS, A., REN, Z., TIAN, Y., LV, X., Ecological Indicators, 106, 2019, p.105508, https://doi.org/10.1016/j.ecolind.2019.105508. [29] YU, Y., WAN, Y., CAMARA, AY., LI, H., Chemosphere, 196, 2018, p. 303, https://doi.org/10.1016/j.chemosphere.2018.01. 002.

[30] CHEN, Y., XIE, T., LIANG, Q., LIU, M., ZHAO, M., WANG, M., WANG, G., Environ. Sci. Pollut. Res., 23, 2016, p. 7757, https://doi.org/10.1007/s11356-015-5930-4.

[31] ZHOU, S., LIU, J., XU, M., LV, J., Environ. Sci. Pollut. Res., 22, 2015, p. 15154, https://doi.org/10.1007/s11356-015-4745-7. 